\title{
DUKUNGAN SOSIAL KELUARGA DAN PROSES REHABILITASI MOTORIK PASIEN STROKE
}

\author{
ARIAWAN WANGSA SAPUTERA, MARIA MANUK, YOHANES KURNIAWAN \\ AKADEMI KEPERAWATAN ADI HUSADA \\ arif4ng@hotmail.com
}

\begin{abstract}
ABSTRAK
Penderita stroke dapat mengalami gangguan motorik. Setelah melewati masa akut, penderita stroke yang mengalami gangguan motorik diharapkan menjalani program rehabilitasi motorik. Proses rehabilitasi motorik penderita stroke membutuhkan dukungan keluarga karena dapat memotivasi dan meningkatkan kepatuhan pasien dalam menjalani program rehabilitasi. Penelitian ini bertujuan untuk menganalisa dukungan keluarga pada pasien stroke dalam menjalani rehabilitasi motorik. Sampel penelitian adalah pasien yang berkunjung ke Puskesmas Sidotopo Wetan yang menderita stroke dan sedang melakukan program rehabilitasi sebanyak 27 orang. Teknik pengambilan sampel menggunakan consecutive sampling. Pengumpulan data menggunakan kuesioner. Analisis data dalam penelitian ini menggunakan uji korelasi Pearson. Hasil uji korelasi Pearson menunjukkan nilai $p=0.496(\alpha<0.05)$ dan nilai $r=-0.137$, dan dari hasil uji tersebut dapat disimpulkan bahwa tidak ada hubungan antara dukungan emosional, penghargaan, informatif, dan instrumental keluarga terhadap proses rehabilitasi motorik penderita stroke. Hal ini dikarenakan sebagian besar penderita tidak tinggal serumah dengan keluarga, sehingga hal ini membuat penderita tidak mendapatkan dukungan keluarga yang optimal. Bila penderita mendapatkan dukungan yang cukup dari keluarga, diharapkan penderita dapat termotivasi untuk merubah gaya hidup sehat secara optimal.
\end{abstract}

Kata kunci: dukungan keluarga, pasien stroke, rehabilitasi motorik

\section{ABSTRACT}

Stroke patients may experience physical motor impaired. After passing through the acute period, stroke patients with physical motor impaired must took a physical motor rehabilitation program. The process of physical motor rehabilitation program needed social family support because family could motivated and increased patient's obedience. The aim of this study was to analyzed relationship between family social support with physical motor rehabilitation program of stroke patients. Samples were patient came to Sidotopo Wetan public health care who suffered a stroke and was conducting a physical motor rehabilitation program as many as 27 people. This study used consecutive sampling. Data was collected using questionnaire and analyzed using Pearson correlation test. Result of this study showed $p=0.496(\alpha<0.05)$ dan nilai $r=-0.137$ so there was not a relationship between emotional, appreciation, informative, and instrumental family support with the patient physical motor rehabilitation process. This was because most patients did not stay together with their family, so this made patients did not get full family support. When patients get enough support from the family, the patient could be motivated to change healthy lifestyle optimally.

Keywords: family support, stroke patient, physical motor rehabilitation 


\section{PENDAHULUAN}

Gangguan motorik pada pasien stroke disebabkan oleh gangguan fungsional otak vocal maupun global akut dengan gejala dan tanda sesuai bagian otak yang terkena akibat gangguan aliran darah ke otak karena pendarahan ataupun non pendarahan yang dapat sembuh sempurna, sembuh dengan cacat atau kematian. Untuk mencegah kecacatan diperlukan pengetahuan keluarga dalam proses rehabilitasi motorik, yaitu melatih anggota gerak atas yang sakit, melatih anggota gerak bawah, dan latihan Keseimbangan. ${ }^{1}$ Proses rehabilitasi motorik pada pasien stroke adalah pemulihan bentuk atau fungsi yang normal setelah sakit untuk dapat mandiri pada semua aktivitas, dimana proses rehabilitasi motorik pasien stroke terbagi atau rehabilitasi pasif dan aktif. Adapun faktor risiko yang memicu tingginya angka kejadian stroke adalah faktor yang tidak dapat dimodifikasi (non-modifiable risk factors) seperti usia, ras, gender, genetic, dan riwayat Transient Ischemic Attack atau stroke sebelumnya. Sedangkan faktor yang dapat dimodifikasi (modifiable risk factors) berupa hipertensi, merokok, penyakit jantung, diabetes militus, obesitas, penggunaan oral kontrasepsi, alkohol, hiperkolesterolemia. Apabila dukungan keluarga tidak ada maka akan menyebabkan dampak psikologis terhadap pasien tersebut. ${ }^{3}$

Penelitian ini bertujuan untuk menganalisa dukungan keluarga pada pasien stroke dalam menjalani rehabilitasi motorik.

\section{METODE}

Dalam penelitian ini teknik sampel yang digunakan adalah consecutive sampling.

Populasi dalam penelitian ini adalah seluruh keluarga yang salah satu anggota keluarganya menderita stroke dan dalam proses rehabilitasi motorik. Sampel dalam penelitian ini adalah penderita stroke di Puskesmas Sidotopo Wetan.

Variabel independen dalam penelitian ini adalah dukungan sosial keluarga. Variabel dependen dalam penelitian ini adalah proses rehabilitasi motorik. Dalam penelitian ini, peneliti menggunakan instrumen yaitu lembar kuesioner untuk variabel independen, sedangkan untuk variabel dependen menggunakan instrument lembar observasi kartu rehabilitasi.
Penelitian ini dilakukan di Puskesmas Sidotopo Wetan selama bulan Juli 2015. Data yang didapat dianalisis dengan menggunakan uji korelasi Pearson.

HASIL

Tabel 1 Distribusi frekuensi karakteristik responden di Puskesmas Sidotopo Wetan pada 04 Juli 2015

\begin{tabular}{|c|c|c|c|}
\hline No & Karakteristik & Frekuensi & $\%$ \\
\hline \multirow[t]{4}{*}{1} & Umur & & \\
\hline & $45-55$ tahun & 11 & 40.7 \\
\hline & $56-65$ & 9 & 33.3 \\
\hline & $66-75$ & 7 & 25.9 \\
\hline \multirow[t]{3}{*}{2} & Jenis kelamin & & \\
\hline & Laki-laki & 8 & 29.6 \\
\hline & Perempuan & 19 & 70.4 \\
\hline \multirow[t]{5}{*}{3} & Pendidikan terakhir & & \\
\hline & SD & 5 & 18.5 \\
\hline & SMP & 8 & 29.6 \\
\hline & SMA & 10 & 37 \\
\hline & PT & 4 & 14.8 \\
\hline \multirow[t]{5}{*}{4} & Pekerjaan & & \\
\hline & PNS & 1 & 3.7 \\
\hline & Swasta & 6 & 22.2 \\
\hline & Wiraswasta & 6 & 22.2 \\
\hline & Tidak bekerja & 14 & 51.9 \\
\hline \multirow[t]{5}{*}{5} & Pendapatan & & \\
\hline & $<$ Rp.500.000,- & 2 & 7.4 \\
\hline & $\begin{array}{l}\text { Rp.1.000.000- } \\
\text { Rp.1.500.000 }\end{array}$ & 10 & 37 \\
\hline & $>$ Rp. 1.500.000,- & 1 & 3.7 \\
\hline & Tidak ada pendapatan & 14 & 51.9 \\
\hline \multirow[t]{3}{*}{6} & Suku Bangsa & & \\
\hline & Jawa & 20 & 74.1 \\
\hline & Madura & 7 & 25.9 \\
\hline \multirow[t]{4}{*}{7} & Lama Menderita Stroke & & \\
\hline & $<1$ tahun & 11 & 40.7 \\
\hline & $1-3$ tahun & 12 & 44.4 \\
\hline & $>3$ tahun & 4 & 14.8 \\
\hline \multirow[t]{4}{*}{8} & Lama Rehabilitasi Mot & & \\
\hline & $<1$ tahun & 14 & 51.9 \\
\hline & $1-3$ tahun & 10 & 37 \\
\hline & $>3$ tahun & 3 & 11.1 \\
\hline \multirow[t]{4}{*}{9} & Tempat Rehabilitasi M & orik & \\
\hline & Rumah sakit & 17 & 63 \\
\hline & Rumah & 7 & 25.9 \\
\hline & Klinik & 3 & 11.1 \\
\hline
\end{tabular}

Menunjukkan bahwa responden yang diteliti sebagian besar berusia 45 - 55 tahun sebanyak 11 responden (40.7\%), sebagian besar berjenis kelamin perempuan sebanyak 19 responden (70.4\%), tingkat pendidikan sebagian besar lulusan SMA sebanyak 10 responden $(37 \%)$, sebagian besar responden tidak bekerja sebanyak 14 responden 
(51.9\%), sebagian besar responden berpenghasilan Rp 1.000.000 - Rp 1.500.000 sebanyak 11 responden $(40.7 \%)$, responden sebagian besar memiliki budaya jawa sebanyak 20 responden (74.1\%), sebagian besar responden menderita stroke selama 1-3 tahun sebanyak 12 responden (44.4\%), sebagian besar responden melakukan rehabilitasi fisik selama $<1$ tahun sebanyak 14 responden (51.9\%), dan sebagian besar responden melakukan rehabilitasi di rumah sakit sebanyak 17 responden (63\%).

Tabel 2 Distribusi frekuensi responden berdasarkan variabel

\begin{tabular}{llllllll}
\hline No & Variabel & \multicolumn{2}{c}{ Baik } & \multicolumn{2}{c}{ Cukup } & \multicolumn{2}{c}{ Kurang } \\
\cline { 3 - 8 } & & n & \% & n & \% & n & \% \\
\hline 1. & $\begin{array}{l}\text { Dukungan } \\
\text { keluarga }\end{array}$ & 4 & 14.8 & 14 & 51.8 & 9 & 33.3 \\
\hline 2. & $\begin{array}{l}\text { Rehabilitasi } \\
\text { Motorik }\end{array}$ & 1 & 3.7 & 12 & 44.4 & 14 & 51.8 \\
\hline \multicolumn{4}{l}{ Uji korelasi Pearson $\mathrm{p}=0.772, \mathrm{r}=-0.059$} \\
\hline
\end{tabular}

Menunjukkan bahwa responden yang mendapat dukungan keluarga baik sebanyak 4 responden (14.8\%), cukup sebanyak 14 responden (51.8\%), dan kurang sebanyak 9 (33.3\%). Sedangkan responden yang melakukan rehabilitasi motorik baik sebanyak 1 responden (3.7\%), cukup sebanyak 12 responden (44.4\%), dan kurang sebanyak 14 responden $(51.8 \%)$. Hasil uji korelasi pearson nilai $\mathrm{p}=0.772$ dan nilai $\mathrm{r}=$ 0.059 , menunjukkan tidak ada hubungan.

\section{PEMBaHASAN}

Berdasarkan hasil penelitian terlihat pada tabel karakteristik menurut usia, diperoleh hasil responden terbanyak penderita stroke berusia 45-55 tahun sebanyak 11 responden (40.7\%). Setiap manusia akan bertambah umurnya, dengan demikian kemungkinan terjadinya stroke semakin besar. Beberapa penelitian membuktikan bahwa $2 / 3$ serangan stroke terjadi pada usia sekitar 65 tahun. Meskipun demikian, bukan berarti usia muda atau usia produktif akan terbebas dari serangan stroke. Penyakit ini disebabkan oleh penurunan suplai darah ke otak. Pada orang dewasa yang lebih tua, penyebab paling sering adalah bekuan darah yang terbentuk di dalam jantung atau pembuluh darah. Hal ini di tandai dengan kerusakan pembuluh darah otak atau kematian jaringan otak.
Berdasarkan tingkat pendidikan sebagian besar responden pendidikan terakhirnya adalah SMA sebanyak 10 responden (37\%). Apabila jenjang pendidikan yang rendah akan berakibat kurangnya pengetahuan / sedikit pengetahuan yang diperoleh, sedangkan apabila jenjang pendidikan tinggi akan berakibat mendapatkan wawasan pengetahuan yang luas. Dengan demikian, tingkat pendidikan dapat mempengaruhi faktor respon psikologis penderita stroke. ${ }^{2}$

Berdasarkan jenis kelamin, hasil responden terbanyak adalah yang berjenis kelamin perempuan sebanyak 19 responden (70.4\%). Pria lebih banyak terkena stroke daripada wanita, yaitu mencapai kisaran 1.25 kali lebih tinggi. Namun pada kenyataannya lebih banyak wanita yang meninggal dunia karena stroke. Hal ini disebabkan karena pria umumnya terkena serangan stroke pada usia muda, sedangkan para wanita justru sebaliknya yaitu saat usianya sudah tua.

Berdasarkan hubungan dukungan sosial keluarga, hasil responden terbanyak adalah memiliki hubungan dukungan keluarga yang cukup sebanyak 14 responden $(51.8 \%)$. Keluarga berfungsi sebagai sistem pendukung bagi anggotanya. Anggota keluarga juga memandang bahwa orang yang bersifat mendukung selalu siap memberikan pertolongan dan bantuan jika di perlukan. Keluarga dipandang sebagai suatu sistem, jika terjadi gangguan pada salah satu anggota keluarga dapat mempengaruhi seluruh sistem. Sebaliknya disfungsi keluarga dapat pula menjadi salah satu penyebab terjadinya gangguan pada anggota keluarga. Peneliti berpendapat bahwa dukungan sosial keluarga sangat diperlukan dalam keberhasilan proses rehabilitasi motorik. Dukungan sosial dapat dikatakan sebagai jaringan hubungan interpersonal yang memberikan persahabatan, bantuan dan dukungan emosional, bantuan, dan penguatan. ${ }^{5}$

Namun dari hasil penelitian ini menyatakan tidak ada hubungan antara kedua variabel. Hal tersebut disebabkan sebagian besar responden berusia 45-55 tahun dan hampir semua anaknya sudah banyak yang mempunyai keluarga masing-masing dan tidak tinggal serumah dengan penderita, sehingga hal ini membuat penderita tidak mendapatkan dukungan keluarga yang optimal. Banyak responden yang sudah tidak 
bekerja lagi, ini menyebabkan kurang mendapatkan dukungan dari temantemannya. Atau mungkin keluarga tidak dapat memutuskan tindakan yang tepat untuk penderita. Kondisi tersebut dapat mengurangi sumber dukungan baik secara emosional, penghargaan, instrumental dan informatif.

Dukungan emosional keluarga adalah bantuan sosial yang melibatkan ungkapan empati, kepedulian, dan perhatian seseorang yang memberikan rasa nyaman memiliki dan dicintai pada waktu mengalami stres. Dukungan penghargaan keluarga merupakan bantuan yang diberikan untuk membangun perasaan berharga, memberikan nilai positif terhadap orang tersebut ditengah keadaannya yang kurang mampu baik secara mental maupun secara fisik. Dukungan informatif keluarga yaitu bantuan berupa pengetahuan, petunjuk, saran, nasehat, instruksi, atau umpan balik, sehubungan dengan kejadian yang dialami seseorang misalnya efek samping dari berbagai pengobatan. Dengan demikian, dapat dikatakan bahwa dengan adanya dukungan keluarga yang efektif diharapkan akan sangat membantu pederita untuk melakukan proses rehabilitasi secara optimal sehingga dapat menghindari risiko stroke lanjutan. ${ }^{4}$

Beberapa sistem dukungan sosial yang berkaitan dengan kesehatan diantaranya, sistem dukungan natural, sistem dukungan teman sebaya, sistem dukungan organisasi keagamaan, sistem dukungan organisasi tenaga professional, kelompok dukungan organisasi yang tidak langsung dengan tenaga profesi kesehatan. Berbagai sistem dukungan sosial yang ada, keluarga merupakan kelompok pendukung yang utama. $^{2}$

Penggunaan dukungan keluarga mempunyai dampak terhadap kesehatan fisik dan mental anggota keluarganya bahkan rendahnya dukungan yang diberikan secara konsisten berhubungan dengan peningkatan angka kesakitan dan kematian. Individu yang mempunyai dukungan keluarga yang kuat lebih cenderung untuk mengadopsi dan mempertahankan perilaku kesehatan yang baru dari para individu yang tidak memiliki dukungan keluarga untuk mengubah perilaku kesehatannya. Dengan demikian, bila pasien stroke mendapatkan dukungan yang cukup dari keluarga, diharapkan pasien dapat termotivasi untuk merubah perilaku untuk menjalani gaya hidup sehat secara optimal sehingga dapat meningkatkan status kesehatan dan menurunkan risiko terjadinya stroke lanjutan. ${ }^{5}$

\section{SIMPULAN}

Berdasarkan hasil dan pembahasan menunjukkan tidak ada hubungan antara dukungan sosial keluarga dengan proses rehabilitasi fisik pasien stroke di Puskesmas Sidotopo Wetan, karena sebagian besar keluarga tidak tinggal serumah dengan pasien, sehingga dukungan yang diberikan tidak optimal.

\section{SARAN}

1. Bagi Responden dan Keluarga

Diharapkan responden dapat menjalankan proses rehabilitasi fisik sesuai dengan jadwal dan keluarga mampu memberikan dukungan secara optimal.

2. Bagi Institusi Pendidikan

Diharapkan dapat menjadi acuan bagi pendidikan untuk pengembangan intervensi keperawatan dimasyarakat terkait rehabilitasi motorik pasien stroke dengan dukungan keluarga guna merubah pola gaya hidup yang sehat.

3. Bagi penelitian selanjutnya

Diharapkan menjadi petunjuk bagi penelitian yang berikutnya terkait jumlah sampel, faktor lain yang mendukung proses rehabilitasi fisik dan intervensi yang dapat meningkatkan kepatuhan dan keberhasilan proses rehabilitasi fisik.

\section{KEPUSTAKAAN}

1. Junaidi, Iskandar. 2004. Panduan Praktis Pencegahan Dan Pengobatan Stroke. Jakarta: Salemba Medika

2. Pudiastuti, Ratna Dewi. 2011. Penyakit Pemicu Stroke. Nuha Medika: Yogyakarta.

3. Mulyatsih, Enny. 2003. Petunjuk Praktis Bagi Pengasuh Dan Keluarga Pasien Pasca Stroke, Jakarta: PT. Gramedia Pustaka Utama

4. Sutrisno. 2007. Pencegahan Stroke. Jakarta: PT. Gramedia Pustaka Utama 